\title{
Effects of Junk Foods on Brain Neurotransmitters (Dopamine and Serotonin) and some Biochemical Parameters in Albino Rats
}

\author{
H. A. Abd Elmonem and E. A. Ali
}

Biological Applications Dept., Nuclear Research Centre (NRC), Inshas, Egypt.

\begin{abstract}
Jutritional HABITS have changed significantly and 1 junk foods have become widely popular, in recent years. The present study aimed to shed the light on the effect of potato chips and / or ketchup consumption on some biochemical parameters. Sixty four male and female albino rats were used in the study. Animals were maintained on $0.25 \mathrm{~g}$ potato chips/ rat and / or $0.125 \mathrm{~g}$ ketchup / rat, 5days a week for 4weeks.

Potato chips showed the lowest body wt gain in the male rats after 4weeks but, ketchup modulated this negative effect of the potato chips in the group of male animals fed on potato chips plus ketchup. Potato chips significantly decreased brain serotonin, liver glutathione (GSH) and catalase (CAT) in both sexes; brain dopamine, serum total proteins, albumin, total globulins, $\alpha_{2}-\& \beta_{1}$-globulins in the females and serum thyroxine $\left(\mathrm{T}_{4}\right)$ in the male rats. Ketchup apparently affected serum $\mathrm{T}_{4}$ and $\mathrm{A} / \mathrm{G}$ ratio in both sexes, brain dopamine and liver GSH in the males in addition to brain serotonin, serum total globulins and $\alpha_{1}$-globulin in the female rats.

Potato chips plus ketchup significantly changed $T_{4}$, dopamine, GSH, CAT, $\alpha_{1}$ and $\alpha_{2}$-globulins in both sexes; serotonin and $\beta_{1}$-globulin in the male rats, total proteins and albumin in the females. It could be concluded that potato chips consumption might induce numerous adverse effects in various body organs.

Keywords: Potato chips, ketchup, $\mathrm{T}_{4}$, dopamine, serotonin, $\mathrm{GSH}, \mathrm{CAT}$, protein fractions.
\end{abstract}

Junk foods are deeply fried, enriched with saturated fat, energy dense and sugar. However, they are poor in micronutrients and fibres. Researchers have found that foods enriched with fats, sugars and salts activate brain to release many of the pleasure chemicals including cortisol, dopamine, galanin and serotonin. Over time, regular consumption of junk foods create imbalances in these 
pleasure chemicals, leading to alter in brain activity in similar to the addictive drugs such as, cocaine or heroin (Johnson and Kenny, 2010). Potato chips have always topped the junk food list. It is well accepted that levels of lipid peroxide, toxic polymer, polar compounds, and oxidative stress increase with time through the frying process and oil oxidation (Velasco et al., 2005).

The high salt and Trans fats (thermally oxidized oils) increase the risk of heart disease and generate free radicals that are involved in the aetiology of many diseases such as cancer, diabetes, arthritis, and cataract (Lunec, 1992). Acrylamide (ACR) is a component that worsens the unhealthy chips.

The ACR concentration in fried potato chips ranged from 376 to $2348 \mu \mathrm{g} /$ $\mathrm{kg}$ (Nojska,et al., 2008). Dietary ACR is largely derived from heat induced reactions (Maillard reaction) between the predominant amino group of the free amino acid precursor asparagine and carbonyl groups of glucose and fructose (Friedman and Levin, 2008). Orally consumed ACR is absorbed into the circulation then distributed to the various organs, and reacts with DNA, neurons, haemoglobin, and essential enzymes, producing several neurotoxicants and germ cell mutagen (Klaunig, 2008 and Rayburn and Friedman, 2010).

Potato chips and ketchup are locally available in every nook and corner. Ketchup contains the antioxidant lycopene which is one of the most efficient reducing free radicals. There is a scanty of literatures that study the effect of these junk foods on the biological functions. Therefore, the present study aimed to shed the light on the effect of these potato chips and / or ketchup on some biochemical parameters in male and female albino rats for 4 weeks.

\section{Material and Methods}

Potato chips and ketchup: They were purchased from the local market. Potato chips were manufactured in Egypt by Chipsy Company with the ingredients of fresh potatoes, vegetable oils and salt. Ketchup was manufactured in Egypt by Heinz ${ }^{\circledR}$ Ketchup Company with the ingredients of tomato concentrate made from red ripe tomatoes, distilled vinegar, high fructose corn syrup, corn syrup, salt, spice and onion powder.

Sixty four male and female rats with a mean body wt ranged from $81-85 \mathrm{~g}$ were supplied from the animal house belonging to Biological Application Dept., Egypt. J. Rad. Sci. Applic., Vol. 25, No. 1-2 (2012) 
Egyptian Atomic Authority, Inshas, Egypt. All animals were housed in stainless steel cages with wire mesh lid and allowed balanced standard diet and water ad libitum. The male and female animals were divided into four groups, each of eight rats / sex as follows: Group1 (G1), animals were maintained on only standard diet and served as control group. Group2 (G2): plain potato chips $(0.25 \mathrm{~g} / \mathrm{rat})$ were allowed to the animals 5 days a week. Group3 (G3), animals were provided with ketchup $(0.125 \mathrm{~g} / \mathrm{rat})$, five days a week. Group4 (G4), animals were maintained on both $0.25 \mathrm{~g}$ potato chips / rat and $0.125 \mathrm{~g}$ ketchup / rat, five days a week. All animals were sacrificed after 4 weeks. Blood samples were collected and centrifuged at 3000 r.p.m. for $15 \mathrm{~min}$ and serum samples were kept frozen at $-20^{\circ} \mathrm{C}$ pending on the biochemical analyses. Liver and brain tissues from each rat were dissected blotted on filter paper and kept a $20^{\circ} \mathrm{C}$ for further analyses. Levels of $\mathrm{T}_{4}$ were determent using radioimmunoassay commercial kits (Institute of Isotopes Co., LTD Budapest). Levels of dopamine and serotonin in brain homogenates were measured by Elisa kit (Uscn Life Science Inc. Wuhan). Activities of GSH and CAT in liver homogenates were estimated by the methods of Jollow et al. (1974) and Chance and Maehly (1955), respectively. Colorimetric determination of total proteins was carried out according to Sonnenwirth (1980). Serum proteins were fractionated after Davis (1964) and calculated according SynGene S. No. $17292 * 14518$ sme*mpcs.

The data were expressed as means \pm S.D. Two-way analysis of variance was performed among the mean values of the groups followed by Duncan's multiple range test, whenever necessary. The statistical difference considered significant at $P<0.05$. All statistical analyses were performed using COSTAT.

\section{Results}

The body wt are represented for various tested groups in Table 1. and Fig. 1-2. There Were a significant decrease of body wt and body wt gain in males of G2 compared to the corresponding values in males of G1.However, a significant increase was recorded in males of G3 and in both sexes of G4 were observed compared to the corresponding control values. Significant differences between males and females were also shown.

Egypt. J. Rad. Sci. Applic., Vol. 25, No. 1-2 (2012) 
Table 1. shows the mean values of $\mathrm{T}_{4}$ levels of the tested groups. There was significant decrease in the level of $\mathrm{T}_{4}$ in the males of $\mathrm{G} 2$ compared to the control group. However, both sexes of animals in G3 or G4 showed significant increases in the levels of $\mathrm{T}_{4}$, compared to the corresponding control values.

TABLE 1. Effect of potato chips and / or ketchup on body wt and levels of $T_{4}$ in albino rats.

\begin{tabular}{|c|c|c|c|c|c|}
\hline \multicolumn{2}{|l|}{ Groups } & G1 & G2 & G3 & G4 \\
\hline \multirow{2}{*}{ Initial body wt } & $0^{\pi}$ & $82.1 \pm 1.5^{\mathrm{a}}$ & $82.4 \pm 0 .^{a}$ & $83.2 \pm 1.9^{\mathrm{a}}$ & $81.1 \pm 2.2^{\mathrm{a}}$ \\
\hline & 오 & $81.6 \pm 1.8^{a}$ & $82.2 \pm 1.4^{\mathrm{a}}$ & $82.1 \pm 1.6^{\mathrm{a}}$ & $83.2 \pm 1.4^{\mathrm{a}}$ \\
\hline \multirow{2}{*}{ Final body wt } & 0 & $99.3 \pm 1.7^{\mathrm{c}}$ & $87.2 \pm 1.9^{d}$ & $124.1 \pm 1.6^{a}$ & $102.5 \pm 1.6^{b}$ \\
\hline & $\bar{p}$ & $94.6 \pm 1.1^{b}$ & $96.1 \pm 2.1^{b}$ & $95.4 \pm 2.7^{b}$ & $102.6 \pm 2.1^{\mathrm{a}}$ \\
\hline \multirow{2}{*}{ Body wt gain \% } & $\begin{array}{l}1 \\
\Delta\end{array}$ & $20.9 \pm 1.5^{\mathrm{c}}$ & $5.8 \pm 1.7^{\mathrm{d}}$ & $47.4 \pm 2.9^{\mathrm{a}}$ & $25.3 \pm 3.5^{b}$ \\
\hline & q & $16.7 \pm 1.2^{b}$ & $16.7 \pm 1.5^{b}$ & $16.3 \pm 1.1^{b}$ & $23.3 \pm 0.4^{\mathrm{a}}$ \\
\hline \multirow[t]{2}{*}{$\mathbf{T}_{4}$} & $\begin{array}{l}1 \\
\mathbf{A}\end{array}$ & $7.18 \pm 1.7^{b}$ & $5.06 \pm 0.7^{c}$ & $9.04 \pm 0.8^{\mathrm{a}}$ & $10.16 \pm 0.9^{a}$ \\
\hline & $\bar{q}$ & $3.48 \pm 0.08^{c}$ & $3.2 \pm 1.3^{\mathrm{c}}$ & $5.24 \pm 0.7^{b}$ & $8.12 \pm 0.6^{a}$ \\
\hline
\end{tabular}

Values are shown as means $\pm \mathrm{SD}$ of $\mathrm{N}=8$, Different superscripts in the same row indicate significant differences between groups at $P<0.05$. $\Delta$ refer to significant differences between sexes.

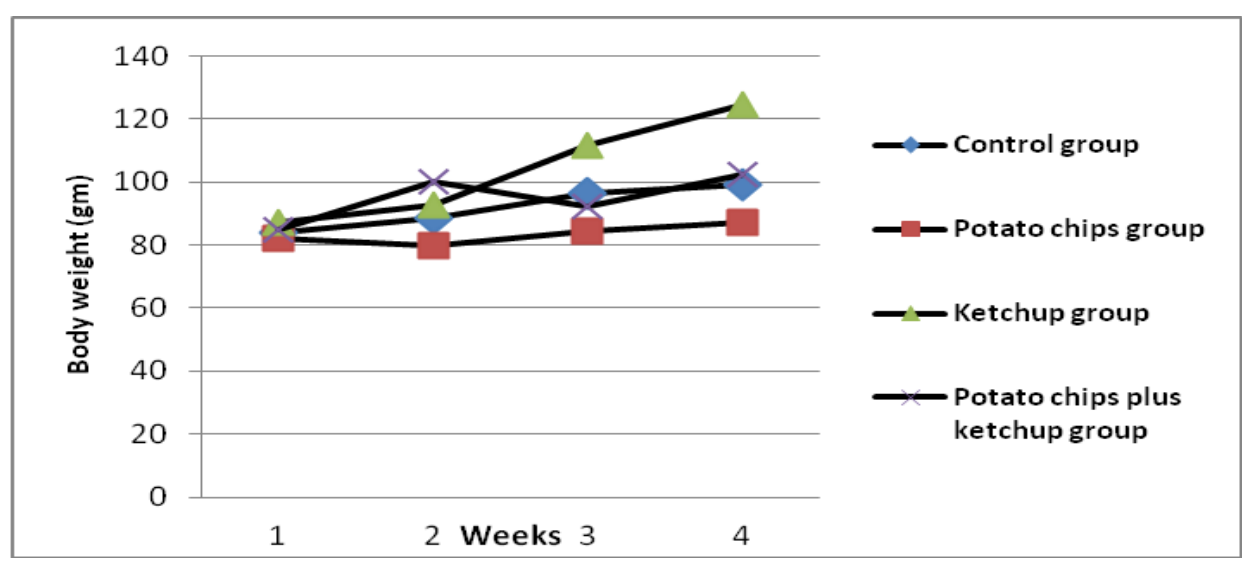

Fig. 1. Effect of potato chips and ketchup on the body wt of male rats throughout 4weeks.

Egypt. J. Rad. Sci. Applic., Vol. 25, No. 1-2 (2012) 


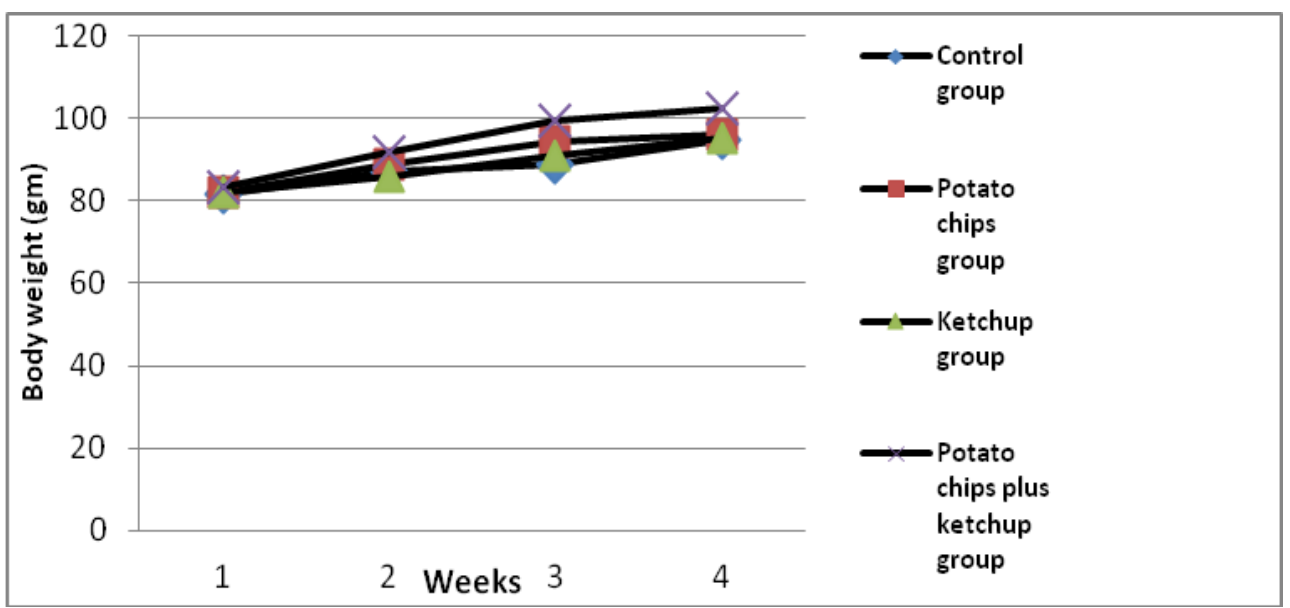

Fig. 2. Effect of potato chips and ketchup on the body wt of female rats throughout 4weeks.

Table 2. shows the levels of dopamine and serotonin in brain of rats fed on potato chips and / or ketchup. In G2, female rats supplied with potato chips showed a significant decrease in level of brain dopamine. However, significant increases were observed in the levels of brain dopamine in males of G3 and in both sexes of G4, compared to the corresponding control values.

The levels of brain serotonin showed significant decrease in both sexes of rats in G2 and in the females of G3. However, significant increase in males of G4 was observed, compared to the corresponding control values. Significant differences between males and females were also shown.

TABLE 2. Effect of potato chips and / or ketchup on the level of dopamine and serotonin in the brain of albino rats.

\begin{tabular}{|c|c|c|c|c|c|}
\hline \multicolumn{2}{|l|}{ Groups } & G1 & G2 & G3 & G4 \\
\hline \multirow{2}{*}{$\begin{array}{l}\text { Dopamine } \\
\text { (ng/g wet of } \\
\text { brain tissue) }\end{array}$} & $\begin{array}{l}\hat{0} \\
\Delta\end{array}$ & $526.4 \pm 24.9^{c}$ & $501.8 \pm 48.7^{\mathrm{c}}$ & $637.6 \pm 53.6^{b}$ & $695.4 \pm 24.0^{a}$ \\
\hline & q & $446.0 \pm 49.7^{b}$ & $391.2 \pm 26.3^{c}$ & $432.4 \pm 23.9^{b c}$ & $537.2 \pm 36.9^{a}$ \\
\hline \multirow{2}{*}{$\begin{array}{l}\text { Serotonin } \\
\text { (ng/g wet of } \\
\text { brain tissue) }\end{array}$} & $\begin{array}{l}\hat{0} \\
\boldsymbol{\Delta}\end{array}$ & $433.2 \pm 47.1^{b}$ & $218.6 \pm 42.9^{c}$ & $423.4 \pm 74.1^{b}$ & $623.6 \pm 38.8^{a}$ \\
\hline & q & $434.0 \pm 91.1^{\mathrm{a}}$ & $162.2 \pm 12.3^{\mathrm{c}}$ & $339.8 \pm 64.1^{b}$ & $430.8 \pm 49.8^{\mathrm{a}}$ \\
\hline
\end{tabular}

Legends as in Table 1. 
TABLE 3. Effect of potato chips and / or ketchup on the levels of GSH and CAT enzyme in the liver of rats.

\begin{tabular}{|c|c|c|c|c|c|}
\hline \multicolumn{2}{|l|}{ Groups } & G1 & G2 & G3 & G4 \\
\hline \multirow{2}{*}{$\begin{array}{c}\text { GSH } \\
(\mu \mathrm{g} / \mathrm{g} \text { tissue })\end{array}$} & $\hat{0}$ & $401.7 \pm 3.3^{b}$ & $331.3 \pm 23.2^{d}$ & $424 \pm 11.2^{\mathrm{a}}$ & $362 \pm 9.5^{c}$ \\
\hline & q & $395 \pm 12.6^{\mathrm{a}}$ & $320 \pm 16.3^{\mathrm{c}}$ & $412 \pm 11.7^{\mathrm{a}}$ & $356.7 \pm 35.8^{b}$ \\
\hline \multirow{2}{*}{$\begin{array}{c}\text { CAT } \\
(\mathrm{IU} / \mathrm{mg})\end{array}$} & $\pi$ & $9.6 \pm 0.14^{\mathrm{a}}$ & $4.3 \pm 0.13^{c}$ & $9.3 \pm 0.28^{a}$ & $8.1 \pm 0.7^{b} \wedge$ \\
\hline & 오 & $9.6 \pm 2.5^{\mathrm{a}}$ & $4.4 \pm 0.31^{c}$ & $9.3 \pm 1.3^{\mathrm{a}}$ & $8.6 \pm 0.2^{b}$ \\
\hline
\end{tabular}

Legends as in Table 1.

Table 3. shows the levels of GSH and CAT activity in the liver of rats supplied with potato chips and / or ketchup. The potato chips significantly suppressed the content of GSH and the activity of CAT in liver tissues of male and female rats in G2, compared to the corresponding control values. Ketchup in G3 did not affect the liver contents of GSH in females and the activity of CAT in both sexes. However, GSH in the males of G3 showed significant increase, compared to the corresponding control value. Potato chips plus ketchup significantly decreased the liver content of GSH and CAT, compared to corresponding control values in both sexes, but showed significant increase, above the value of animals provided with potato chips.

TABLE 4. Effect of potato chips and / or ketchup on the level of serum total proteins, albumin, globulins and $\mathrm{A} / \mathrm{G}$ ratio in albino rats.

\begin{tabular}{|c|c|c|c|c|c|}
\hline \multicolumn{2}{|c|}{ Groups } & G1 & G2 & G3 & G4 \\
\hline \multirow{2}{*}{$\begin{array}{c}\text { Total } \\
\text { proteins }\end{array}$} & $\hat{0}$ & $6.22 \pm 0.29^{\mathrm{a}}$ & $5.85 \pm 0.24^{a}$ & $6.4 \pm 0.85^{\mathrm{a}}$ & $5.71 \pm 0.39^{\mathrm{a}}$ \\
\hline & ot & $6.5 \pm 0.41^{\mathrm{a}}$ & $5.6 \pm 0.39^{b}$ & $6.8 \pm 0.72^{\mathrm{a}}$ & $5.9 \pm 0.24^{b}$ \\
\hline \multirow{2}{*}{ Albumin } & s & $2.27 \pm 0.11^{\mathrm{a}}$ & $2.09 \pm 0.08^{\mathrm{a}}$ & $2.2 \pm 0.24^{\mathrm{a}}$ & $2.11 \pm 0.09^{a}$ \\
\hline & o & $2.47 \pm 0.1^{\mathrm{a}}$ & $2.05 \pm 0.16^{c}$ & $2.33 \pm 0.23^{\text {ab }}$ & $2.17 \pm 0.14^{b c}$ \\
\hline \multirow{2}{*}{$\begin{array}{c}\text { Total } \\
\text { globulin }\end{array}$} & o & $3.94 \pm 0.2^{\mathrm{a}}$ & $3.77 \pm 0.19^{a}$ & $4.17 \pm 0.61^{\mathrm{a}}$ & $3.58 \pm 0.32^{\mathrm{a}}$ \\
\hline & $q$ & $4.05 \pm 0.35^{b}$ & $3.53 \pm 0.23^{\mathrm{c}}$ & $4.47 \pm 0.45^{\mathrm{a}}$ & $3.77 \pm 0.23^{\text {bc }}$ \\
\hline \multirow{2}{*}{ A/G ratio } & $\hat{0}$ & $0.57 \pm 0.01^{\text {ab }}$ & $0.55 \pm 0.01^{b c}$ & $0.53 \pm 0.02^{c}$ & $0.59 \pm 0.03^{\mathrm{a}}$ \\
\hline & 우 & $0.62 \pm 0.05^{\mathrm{a}}$ & $0.59 \pm 0.05^{\mathrm{a}}$ & $0.53 \pm 0.01^{b}$ & $0.57 \pm 0.05^{\mathrm{a}}$ \\
\hline
\end{tabular}

Legends as in Table 1.

The levels of total proteins, albumin, globulins and $\mathrm{A} / \mathrm{G}$ ratio, in addition to serum globulin fractions of the different tested groups are presented as means \pm standard deviations in Tables 4-5. The levels of total proteins, albumin and total globulins significantly decreased in females of G2 and G4, compared to the corresponding control values, with the exception of total globulins in the females in G4. However, ketchup significantly increased total globulins in the

Egypt. J. Rad. Sci. Applic., Vol. 25, No. 1-2 (2012) 
females but reduced $A / G$ ratio in the males and females. The significant reduction of $\alpha_{1}$ and $\alpha_{2}$ globulins were observed in both sexes of G4 that supplied with potato chips plus ketchup, in addition to $\alpha_{2}$ globulin of females in G2. However, ketchup apparently increased $\alpha_{1}$ globulin of females in G3 compared to the corresponding control values. The level of $\beta_{1}$ globulin was significantly suppressed in the females of G2 and in males of G4, compared to the corresponding control values.

TABLE 5. Effect of potato chips and / or ketchup on the level of serum globulin fractions in albino rats.

\begin{tabular}{|c|c|c|c|c|c|}
\hline \multicolumn{2}{|l|}{ Groups } & G1 & G2 & G3 & G4 \\
\hline \multirow{2}{*}{$\alpha_{1}$-globulin } & $\hat{\sigma}$ & $0.39 \pm 0.05^{a}$ & $0.34 \pm 0.01^{\mathrm{ab}}$ & $0.42 \pm 0.09^{a}$ & $0.28 \pm 0.06^{b}$ \\
\hline & 우 & $0.37 \pm 0.01^{b}$ & $0.32 \pm 0.01^{\text {bc }}$ & $0.45 \pm 0.06^{\mathrm{a}}$ & $0.30 \pm 0.08^{c}$ \\
\hline \multirow{2}{*}{$\alpha_{2}$-globulin } & $\hat{0}$ & $0.43 \pm 0.06^{a b}$ & $0.37 \pm 0.09^{b c}$ & $0.49 \pm 0.03^{\mathrm{a}}$ & $0.35 \pm 0.04^{c}$ \\
\hline & 우 & $0.48 \pm 0.09^{a}$ & $0.34 \pm 0.08^{b}$ & $0.53 \pm 0.1^{\mathrm{a}}$ & $0.37 \pm 0.05^{b}$ \\
\hline \multirow{2}{*}{$\alpha_{3}$-globulin } & $\delta^{1}$ & $0.34 \pm 0.09^{\mathrm{ab}}$ & $0.32 \pm 0.06^{b}$ & $0.41 \pm 0.03^{\mathrm{a}}$ & $0.30 \pm 0.05^{b}$ \\
\hline & q & $0.36 \pm 0.13^{a b}$ & $0.30 \pm 0.05^{b}$ & $0.45 \pm 0.09^{a}$ & $0.32 \pm 0.03^{b}$ \\
\hline \multirow{2}{*}{$\beta_{1}$ - globulin } & $\sigma^{\lambda}$ & $0.76 \pm 0.10^{\mathrm{a}}$ & $0.66 \pm 0.09^{a b}$ & $0.64 \pm 0.07^{a b}$ & $0.62 \pm 0.09^{b}$ \\
\hline & q & $0.78 \pm 0.14^{a}$ & $0.61 \pm 0.09^{b}$ & $0.69 \pm 0.09^{a b}$ & $0.64 \pm 0.06^{\mathrm{ab}}$ \\
\hline \multirow{2}{*}{$\beta_{2}$ - globulin } & $\overline{0}$ & $0.49 \pm 0.05^{\mathrm{a}}$ & $0.46 \pm 0.05^{\mathrm{a}}$ & $0.49 \pm 0.19^{a}$ & $0.50 \pm 0.13^{\mathrm{a}}$ \\
\hline & ㅇ & $0.50 \pm 0.04^{a}$ & $0.42 \pm 0.05^{a}$ & $0.50 \pm 0.07^{\mathrm{a}}$ & $0.52 \pm 0.11^{a}$ \\
\hline \multirow{2}{*}{$\gamma_{1^{-}}$globulin } & $\hat{\sigma}$ & $1.30 \pm 0.24^{\mathrm{a}}$ & $1.30 \pm 0.14^{\mathrm{a}}$ & $1.40 \pm 0.27^{\mathrm{a}}$ & $1.27 \pm 0.10^{\mathrm{a}}$ \\
\hline & 오 & $1.29 \pm 0.09^{\mathrm{a}}$ & $1.28 \pm 0.10^{\mathrm{a}}$ & $1.50 \pm 0.03^{\mathrm{a}}$ & $1.30 \pm 0.10^{\mathrm{a}}$ \\
\hline \multirow{2}{*}{$\gamma_{2}$ - globulin } & $\hat{0}$ & $0.26 \pm 0.50^{a}$ & $0.26 \pm 0.10^{a}$ & $0.28 \pm 0.06^{\mathrm{a}}$ & $0.26 \pm 0.03^{\mathrm{a}}$ \\
\hline & 웅 & $0.27 \pm 0.07^{a}$ & $0.26 \pm 0.09^{a}$ & $0.28 \pm 0.02^{a}$ & $0.28 \pm 0.03^{\mathrm{a}}$ \\
\hline
\end{tabular}

Legends as in Table 1 .

\section{Discussion}

Potato chips are common food restaurants all over the world. These contain high levels of the toxic and carcinogenic by products, ACR (Nojska et al., 2008). Potato chips are also enriched with thermally oxidized oil and high salts (Lunec, 1992).

The lowest significant decrease in the final body wt was observed in males of G2, females in the same group showed the same body wt of females in control. These findings might reflect that the male rats were more sensitive to the harmful effect of ACR in potato chips than the females. These obtained results are in agreement with Arora and Gupta (2011), who observed that administration of $25 \mathrm{mg} / \mathrm{kg} /$ day of ACR to male and female albino mice for a Egypt. J. Rad. Sci. Applic., Vol. 25, No. 1-2 (2012) 
period 91 days showed a significant decrease in final body wt of males than females. Sharma and Jyotsna (2008) and Ali and Abd Elmonem (2011) attributed the loss of body wt to the neurotoxicity of ACR that cause sluggish movements, muscular and nervous weakness and alterations in hunger and thirst centres in the brain, which result in decrease feed and water consumptions. The observed decrease in the mean body wt gains of the animals in the present study might be attributed to the disturbed basal metabolic rate also; Sharma and Jyotsma (2008) found that ACR causes endocrine disruption of thyroid gland. Moreover, other studies showed reduced food intakes, decrease body wt gains, increased tissue wt, increased rate of haemolysis or histopathological lesions in animals fed on highly autoxidised or thermoxidized oils (Huang et al., 1988). The significant increase in body wt gain in the males of G3 might be attributed to the presence of high fructose corn syrup in ketchup. Fructose metabolism leads to an accumulation of intermediates of glycolysis that are converted to glycerol and acetyl-coenzyme A followed by synthesis of fatty acids, very-lowdensity lipoproteins, and triglycerides (Lim et al., 2010). The significant increase in the body wt of females in G4 could be attributed to presence of lycopene in ketchup, the superior antioxidant, lycopene might reduce the intoxication of ACR. Moreover, the combination of fat and carbohydrate in potato chips and fructose in ketchup might increase the body wt gains of both females and males. These are supported by the study of Harris et al. (2003), who found that, the combination of both a fat load and a glycemic load exaggerate the insulin response and promote further wt gain. The significant difference between male and female body wt might reflect the effect of sex hormone differences. Arora and Gupta (2011) postulated that males are more sensitive than females. They also attributed that the male rats have higher capacity to metabolize xenobiotics than the females.

The significant decrease of $\mathrm{T}_{4}$ level in males maintained on potato chips might be attributed to the presence of ACR and thermally oxidized oil. The present finding is in agreement with Sharma and Jyotsma (2008). ACR and oxidized oil intoxication might induce deiodination and $\mathrm{T}_{4}$ elemination from blood. Moreover, Eder and Stangl (2000) concluded that the dietary oxidized oils reduce vitamin $\mathrm{E}$ that affect the selenium status of tissues and interfere with the metabolism of thyroid hormones. However, each of ketchup and potato 
chips plus ketchup significantly increased the levels of $T_{4}$ in both sexes that could be attributed to the high fructose in ketchup. These are in agreement with Hallfrisch et al. (1985) who reported increase in the level of $\mathrm{T}_{4}$ with increase of fructose.

The present study demonstrated that rats in G2 showed significant decreases in the level of brain dopamine in the females and brain serotonin in both sexes. These could be attributed to the presence of ACR. The obtained results are in agreement with Husain et al. (1987) who showed decrease of dopamine and serotonin contents in young brain rats exposed to ACR. The ACR might interact with tyrosine and tryptophan (the precursor amino acids for synthesis of dopamine and serotonin, respectively). Reactivity of ACR with tyrosine and tryptophan might presumably result in an inhibition of biosynthesis of dopamine and serotonin. Same mechanism was explained previously by Dixit et al. (1980). Richard and LoPachin (2004), reported that the nerve terminal is the primary site for ACR action where inhibits the corresponding membranefusion processes, impairs neurotransmitter release and promotes downstream degeneration. The same authors suggested that the electrophilic nature of ACR contributes to adduct formation of sulfhydryl groups on certain proteins that are critically involved in membrane fusion. The obtained results revealed that consumption of potato chips plus ketchup significantly increased dopamine and serotonin. This could be attributed to the presence of lycopene in ketchup, that might reduce the intoxication of ACR. The significant differences between males and females might be due to the hormonal differences such as Adrenal, Estrogen and thyroid (Valencia-Sanchez et al., 1997).

The obtained results showed significant suppression in the liver GSH content and activity of CAT in rats fed on potato chips. These might reflect oxidative stress generated by ACR and oxidative oils in potato chips. Velasco et al. (2005) reported increase levels of oxidative stress, lipid peroxide, toxic polymer, polar compounds in potato chips during the frying process. In addition Khan et al. (2011) proved that ACR increases reactive oxygen species in liver HepG2 cells. The study of Mansour et al. (2008) showed significant decrease in GSH concentration and CAT activity in rats under oxidative stress resulting 
from thermally oxidized oil. Moreover Khan et al. (2011) found significant decrease in hepatic GSH content and CAT activity in female Sprague-Dawley rats injected with $6 \mathrm{mg}$ ACR/kg bw/15 days. Tong et al. (2004) reported that ACR undergoes biotransformation and conjugates with GSH. They postulated also that GSH is probably the major route of detoxification. The significant increases of GSH and CAT in animals supplied with potato chips plus ketchup in G4 compared to animals of G2 might reflect the protective role of lycopene. Lycopene is a carotenoid found naturally in tomatoes and has a chemical structure with large numbers of conjugated double bonds (Tapiero et al., 2004) that might interact to decrease the deleterious effect of ACR. Tang et al. (2009) found that lycopene might actually stimulate the endogenous enzymatic antioxidant system. Lycopene might also activate GSH and CAT in order to minimize oxidative stress caused by ACR.

The present study showed that the total proteins and albumin were significantly decreased in the females of G2 and G4 (as shown in Table 4-5), these might be due to the hepatic lesions caused by ACR and thermally oxidized oil in potato chips. ACR molecule has two reactive sites, the conjugated double bond and the amide group, which is able to conjugate with the -SH group of a sulfur containing amino acids and $\alpha-\mathrm{NH} 2$ group of a free amino acid (Exon, 2006). These could explain the depletion of amino acids needed for protein synthesis. The obtained results are consistent with the results of Khan et al. (2011) who showed steady decreases in hepatic protein level with the increase in doses of ACR which is indicative to the retarded protein synthesis, change in protein metabolism or leaking out of protein reserves from hepatocytes . ElDeen and Eid (2010) observed that the intake of thermally treated sunflower oil significantly decreased serum total protein and albumin.

The significant decrease in $\alpha_{1}$ and $\alpha_{2}$ globulins of animals in G4 might be attributed to decrease in their synthesis due to stress of ACR. The $\alpha_{1}$ fraction consists mainly of $\alpha_{1}$ antitrypsin, the significant decrease of this fraction reflected $\alpha_{1}$ antitrypsin deficiency (Laurell and Eriksson, 1963). The decrease in $\alpha_{2}$ globulin could belong mostly to decrease in the high molecular wt $\alpha_{2}$ macroglobulin which possesses an inhibitory activity against proteinases (Heimburger, 1972). Therefore, a decrease in $\alpha_{2}$ macroglobulin might enhance the proteinases activity that might indicate in vivo haemolysis. The significant Egypt. J. Rad. Sci. Applic., Vol. 25, No. 1-2 (2012) 
increase in $\alpha_{1}$ globulin of G3 supplied with ketchup might be indicative to acute phase protein or breakdown of red blood cell and other cellular component. The significant decrease in $\beta_{1}$ globulin leads mostly to decrease in $\beta_{1}$ transferrin which in turn might lead to iron toximea (Rand et al., 1996).

\section{Conclusion}

It could be concluded that potato chips consumption might induce numerous adverse effects in various body organs. However, ketchup could modulate some of these adverse effects but, augmented others.

\section{References}

Ali, E.A. and Abd Elmonem, H. A. (2011) Hazardous effects of potato chips and ketchup (fast food) consumption on albino rats. Isotope Rad. Res., 43, (Prss).

Arora, M. and Gupta, M. (2011) Anatomical and morphological abnormalities produced by dermal application of acrylamide in male and female swiss albino mice. Indian JLS., 1, 2231.

Chance, B. and Maehly, A. C. (1955) Assay of catalase and peroxidases. Method. Enzymol., 11, 764.

Davis, B. (1964) Disk electrophoresis. II Method and application to human serum protein. Ann. N.Y. Acad. Sci., 929, 404.

Dixit, R., Mukhtar, H., Seth, P. K. and Krishna Murti, C. R. (1980) Binding of acrylamide with gluathione-S transferase. Chem. Biol. Interact., 32, 353.

Eder, K. and Stangl, G. I. (2000) Plasma thyroxine and cholesterol concentrations of miniature pigs are influenced by thermally oxidized dietary lipids, J. Nutr., 130, 116.

El-Deen, N. A. and Eid, M. (2010) Efficacy of curcumin to reduce hepatic damage induced by alcohol and thermally treated oil in rats. Vet. Itali., 46, 83.

Exon, J. H. (2006) A review of toxicology of acrylamide. J. Toxicol. Environ. Helth., 9, 397.

Friedman, M. and Levin, C. E. (2008) Review of methods for the reduction of dietary content and toxicity of acrylamide. J. Agric. Food Chem., 56, 6113.

Hallfrisch, J., Reiser, S., Prather, E. S. and Canary, J. J. (1985) Relationships of glucoregulatory hormones in normal and hyper insulinemic men consuming fructose. Nutri. Res., 5, 585.

Harris, R. B., Mitchell, T. D. and Hebert, S. (2003) Leptin-induced changes in body composition in high fat-fed mice. Exp. Biol. Med., 228, 24.

Egypt. J. Rad. Sci. Applic., Vol. 25, No. 1-2 (2012) 
Heimburger, N. (1972) Proteinase inhibition in human serum. In: Pulmonary emphysema and proteolysis. Mittmam, C.(ed.) N. Y. Academic, pp. 307-310.

Huang, C. J., Cheung, N. S. and Lu, V. R. (1988) Effects of deteriorated frying oil and dietary protein levels on liver microsomal enzymes in rats. J. Am. Oil. Chem. Soc., 65, 1796.

Husain, R., Dixit, R., DAS, M. and Seth, P. K. (1987) Neurotoxicity of acrylamide in developing rat brain: Changes in the levels of brain biogenic amines and activities of monoamine oxidase and acetylcholine esterase. Ind. Health, 25, 19.

Johnson Paul, M. and Kenny Paul, J. (2010) Addiction-like reward dysfunction and compulsive eating in obese rats: Role for dopamine D2 receptors. Nat. Neurosci.., 13, 635.

Jollow, D. J., Mitchell, J. R., Zampaglione, N. and Gillete, J. R. (1974) Bromobenzene induced liver necrosis. Protective role of glutathione and evidence for 3,4-bromobenzene oxide as a hepatotoxic metabolite. Pharmacology, 11, 151.

Khan, M. R., Afzaal, M., Saeed, N. and Shabbir, M. (2011) Protective potential of methanol extract of Digera muricata on acrylamide induced hepatotoxicity in rats. Afr. J. Biotechnol ., 10, 8456.

Klaunig, J. E. (2008) Acrylamide carcinigenecity. J. Agric. Food Chem., 56, 5984.

Laurell, C. B. and Eriksson S. (1963) The electrophoretical alpha 1 globulin pattern of serum in alpha 1 antitrypsin deficiency.Scand. J. Clin. Lab. Invest., 15, 132.

Lim, J. S., Mietus-Snyder, M., Valente, M., Schwars, J. M. and Lustig, R. H. (2010) The role of fructose in pathogenesis of NAFLD and the metabolic syndrome. Nat. Rev. Gastroenterol. Hepatol., 7, 251.

Lunec, H. (1992) Oxygen radicals, their measurement and role in major diseases. JIFCC, 14, 58 .

Mansour, M., Ibrahim, E. M., El-Kholy, M. M. and El-Madawy, S. A. (2008) Antioxidant and histopathological effect of catechin and neem leaves extract in acrylamide toxicity of rats. Egypt. J. Comp. Clinic. Pathol., 21, 290.

Nojska, H ., Gielecińska, I., Marecka, D. and Kłys, W. (2008) Study of the influence of raw material and processing conditions on acrylamide level in fried potato chips. Rocz. Panstw. Zakl. Hig., 59, 163.

Rand, M. L., Harfensit, E. J. and Murray, R. K. (1996) Plasma proteins immunoglobulins and blood coagulation In: Harper,s Biochemistry, R.K. Murray, Granner, D.K.,.Mayes, P.A. Rodwell V.W. (eds) 24th edition, Los Atlos, California, pp. 707-719.

Rayburn, J. R. and Friedman, M. (2010) 1-Cysteine, N-Acetyl-1-cysteine, and Glutathione Protect Xenopus laevis Embryos against Acrylamide-Induced

Egypt. J. Rad. Sci. Applic., Vol. 25, No. 1-2 (2012) 
Malformations and Mortality in the Frog Embryo Teratogenesis Assay. $J$ Agric Food Chem., 58, 11172.

Richard, M. and LoPachin, (2004) The Changing view of acrylamide neurotoxicity. NeuroToxicol., 25, 617.

Sharma, A. and Jyotsana, A. (2008) Effects of oral exposure of acrylamide on plasma levels of thyroid hormones and haematological parameters in the swiss albino mice J. Asian J. Exp. Sci., 22, 317.

Sonnenwirth, A. C. (1980) Bacteriology. In: Gradwohl's Clinical Laboratory Methods and Diagnosis. $8^{\text {th }}$ edition. (Eds.): A.C. Sonnenwirth and L. Jarrett. The C.V. Mosby Company, pp. 1391-1405.

Tang, X., Yang, X., Peng, Y. and Lin J. (2009) Protective effects of lycopene against $\mathrm{H} 2 \mathrm{O} 2$-induced oxidative injury and apoptosis in human endothelial cells. Cardiovasc. Drugs Ther., 23, 439.

Tapiero, H., Townsend, D. M. and Tew, K. D. (2004) The role of carotenoids in the prevention of human pathologies. Biomed. Pharmacother., 58, 100.

Tong, G. C., Cornwell, W. K. and Means, G. E. (2004) Reactions of acrylamide with glutathione and serum albumin. Toxicol. Lett., 147, 127.

Valencia-Sánchez, A., Esparza-Avalos, N. S., Cruz, M. L. and Ortega-Corona, B. G. (1997) Amine neurotransmitter levels in male and female rats through developmental periods. Arch. Androl., 39, 79.

Velasco, J., Marmesat, S., Berdeaux, O., Marquez-Ruiz, G. and Dobarganes, C. (2005) Quantitation of short-chain glycerolbound compounds in thermoxidized and used frying oils. A monitoring study during thermoxidation of olive and sunflower oils. J. Agric. Food Chem., 53, 4006.

Received: 18/10/2012;

accepted: 26/12/2012

Egypt. J. Rad. Sci. Applic., Vol. 25, No. 1-2 (2012) 


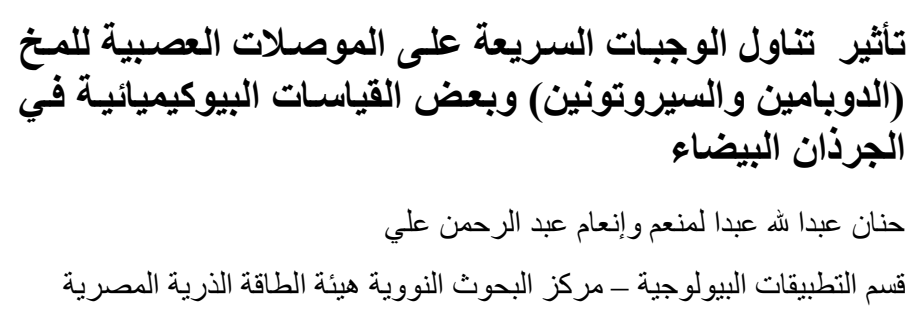

في السنوات الأخيرة، تغيرت العادات الغذائية بشكل كبير والوجبات

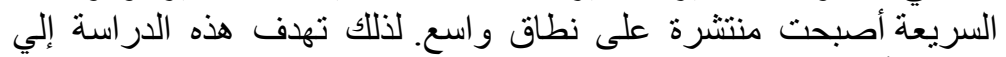

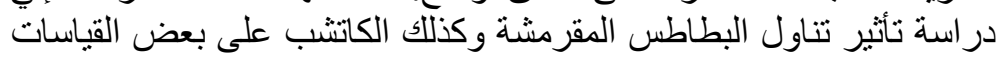

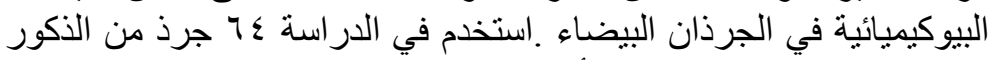

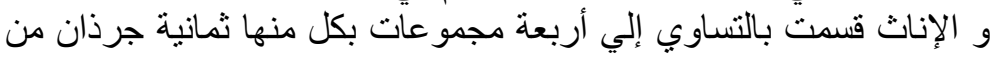

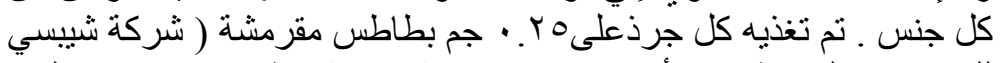

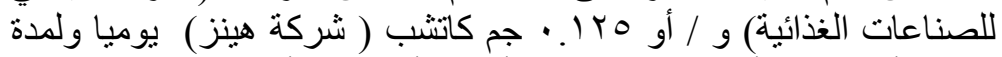

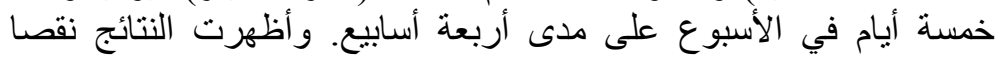

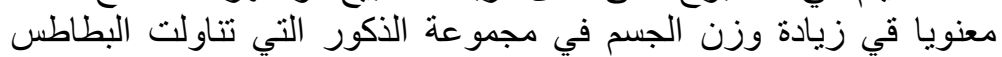

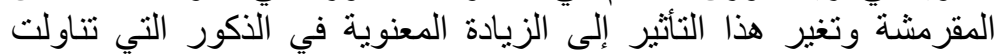

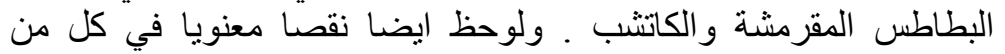

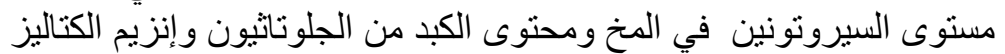

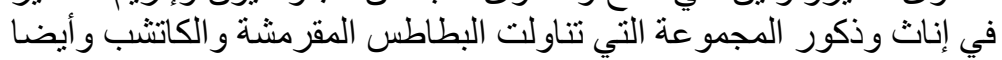

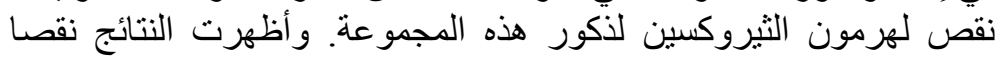

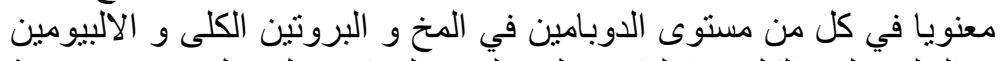

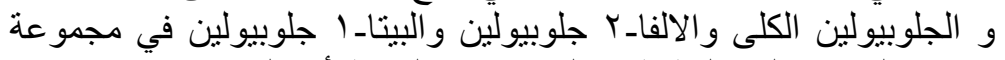

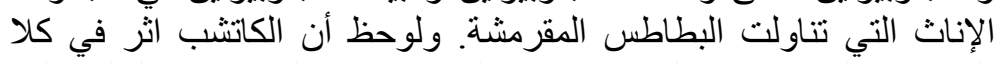

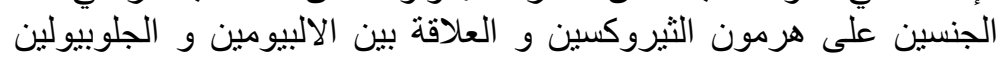

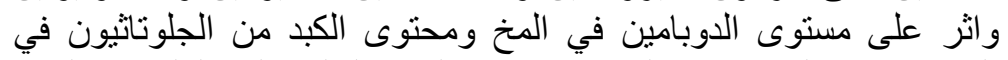

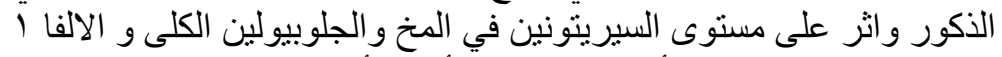

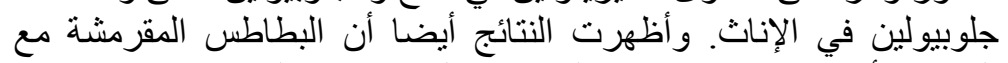

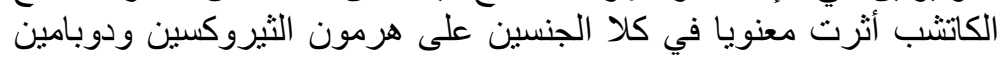

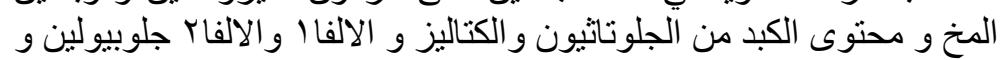
أثرت على البروتين الكلى و الالبيومين في الإناتئ.

Egypt. J. Rad. Sci. Applic., Vol. 25, No. 1-2 (2012) 